\title{
Christopher Munn, Anglo-China: Chinese People and British Rule in Hong Kong, 1841-1880
}

Richmond: Curzon Press, 2001. xvii +460 pp. Hardback.

\section{Peter Wesley-Smith}

\section{OpenEdition}

\section{Journals}

Édition électronique

URL : http://journals.openedition.org/chinaperspectives/249

DOI : $10.4000 /$ chinaperspectives. 249

ISSN : 1996-4617

\section{Éditeur}

Centre d'étude français sur la Chine contemporaine

Édition imprimée

Date de publication : 1 février 2003

ISSN : 2070-3449

\section{Référence électronique}

Peter Wesley-Smith, «Christopher Munn, Anglo-China: Chinese People and British Rule in Hong Kong, 1841-1880 », China Perspectives [En ligne], 45 | january-february 2003, mis en ligne le 22 août 2006, consulté le 21 septembre 2020. URL : http://journals.openedition.org/chinaperspectives/249 ; DOI : https://doi.org/10.4000/chinaperspectives.249

Ce document a été généré automatiquement le 21 septembre 2020

(C) All rights reserved 


\title{
Christopher Munn, Anglo-China: Chinese People and British Rule in Hong Kong, 1841-1880
}

Richmond: Curzon Press, 2001. xvii + 460 pp. Hardback.

\author{
Peter Wesley-Smith
}

Let me begin by declaring an interest: the author of this superb book is a friend of mine (though an indifferent correspondent), he cites my work (though too infrequently), and he includes me in his list of people deserving special (though insufficiently profuse) thanks. I read several chapters in draft form some years ago and was expecting a thoroughly good read. That is what we got. Munn's theme is the notion of British Hong Kong as the conjunction of East and West, a constructive engagement between cultures, and a standing demonstration of British good government in Asia. This-"AngloChina"-was the vision and the boast of the colony's founders. But for the first thirty or so years of British rule it came nowhere near fulfilment. Munn suggests that by 1881 it was at least coming closer, though the most he can point to is the growth of a Chinese bourgeoisie, a degree of economic prosperity among Chinese merchants, and the beginnings of indigenous leadership through such institutions as the Tung Wah Hospital and the Po Leung Kuk. Grossly anti-Chinese legislative measures were however largely still in place, only one Chinese (born in Singapore) had been appointed to the Legislative Council (and only in 1880), and Chinese membership of the Executive Council was still decades away (1926). Obstruction more than co-operation, racial division rather than equality, repression not liberation: these are surely what characterised governance in Hong Kong during the nineteenth century and indeed into the twentieth. Munn's interpretation pleasingly advances Pope Hennessy's reputation (and, surprisingly, MacDonnell's, whose uncompromising policies "were essential preconditions for the apotheosis of the Chinese bourgeoisie during the Hennessy years" (p. 369)), for Hennessy's attitudes and sympathies, if disliked by the non-Chinese colonists, were in tune with the future as much as the aspirations of the past. What was emerging during Hennessy's governorship was an embryonic partnership between Chinese élite groups and the colonial government: scarcely sufficient to substantiate 
Anglo-China rhetoric, but a significant development nonetheless. Munn's treatment of it links with and pays deserving tribute to the work of Carl Smith and Elizabeth Sinn and shows how the narrative might be carried forward. This, like most colonial histories, is a study of government, but with a major focus on the legal system. Part Two, "Crime and Justice", is in some ways the meat of the book, for the rule of law was perhaps the core ingredient of British imperialist self-satisfaction and an ideal more dramatically subverted than any other. Instead of an even-handed system that was no respecter of persons, Hong Kong in its early years suffered the illegitimate application of Chinese law as much as English, draconian legislation, domineering officialdom, illegal and often savage punishments, discrimination between defendants on the grounds of race and class, bribery, intimidation of witnesses, malicious accusations and prosecutions, a paucity of defence counsel and interpreters, incompetent judges and court staff, unsatisfactory judicial premises, unscrupulous lawyers, and racially exclusive juries which routinely displayed contempt for accused orientals. The judicial system at all levels was "systematically biased against Chinese and other non-European defendants" (p. 251). This went hand-in-hand with intrusive schemes of governance: intensive policing, emergency powers, registration of persons, curfews, deportation, licensing, and so on. Indirect rule or non-intervention, also part of the Anglo-China myth, was demonstrably absent. Add to all this police extortion, large-scale corruption, protection rackets, and venal high-ranking officials and the claim that British traditions of government and justice were superior looks very thin. Munn writes well and usually finds the telling quote and the apt illustration. His documentation is impressive, his material rich and often entertaining, his typos are few. I do not know if a paperback version is planned, but if Frank Welsh's history of Hong Kong finds a place in airport bookshops there ought to be a ready sale for Munn's book. In some respects the timing is impeccable: with the British period now superseded, a new view of the colonial relationship is appropriate (and long overdue), one which reflects neither the complacency of the colonial historians nor the ideological rigidity of the Peking school of scholars. Munn has supplied a more thorough and honest examination of the roots of governance in British Hong Kong against which later developments, right up to and beyond 1997, can be assessed. It is an impressive achievement. 